\title{
TOTAL CLIPLESS CHOLECYSTECTOMY BY MEANS OF HARMONIC SEALING
}

\author{
Colecistectomia laparoscópica totalmente ultrassônica sem uso de clipe metálico
}

Almino Cardoso RAMOS ${ }^{1}$, Manoela Galvão RAMOS ${ }^{1}$, Manoel dos Passos GALVÃO-NETO ${ }^{1}$, Josemberg MARINS ${ }^{2}$, Eduardo Lemos de Souza BASTOS ${ }^{1}$, Natan ZUNDEL ${ }^{3}$

From the ${ }^{1}$ Gastro Obeso Center, São Paulo, SP, Brasil; ${ }^{2}$ Universidade Federal de Pernambuco, Recife, PE, Brasil; e ${ }^{3}$ Florida International University ( ${ }^{1}$ Gastro Obeso Center, ${ }^{2}$ Federal University of Pernambuco, ${ }^{3}$ Florida International University)- FIU, Miami, USA

\section{HEADINGS - General surgery.} Laparoscopic cholecystectomy. Harmonic shears.
ABSTRACT - Background: In traditional laparoscopic cholecistectomy, the cystic duct and artery are commonly closed by metallic clips just before their division. Although the placement of these clips for occluding cystic artery and duct can be considered safe, biliary leaks and bleeding may occur especially by its dislodgement. Aim: To report a prospective case-series in total clipless cholecystectomy by means of harmonic shears for closure and division of the artery and cystic duct as well removal of the gallbladder from the liver. Methods: Was evaluate a series of 125 patients who underwent laparoscopic cholecystectomy where the sealing and division of cystic artery and duct was carried out only by harmonic shears. The intact extracted gallbladder was submitted to a reverse pressure test for assessment of the technique safety by means of $\mathrm{CO}_{2}$ insuflation. Results: The most common indication for surgery was gallstones. The mean operative time was $26 \mathrm{~min}$ and all gallbladders were dissected intact from the liver bed. There was no mortality and the overall morbidity rate was $0.8 \%$ with no hemorrhage or leaks. The reverse pressure test showed that all specimens support at least $36-\mathrm{mmHg}$ of pressure without leaking. Conclusion: The harmonic shears is effective and safe in laparoscopic cholecystectomy as a sole instrument for sealing and division of the artery and cystic duct. The main advantages could be related to the safety and decreased operative time.

\section{Correspondence:}

Almino Cardoso Ramos

E-mail: ramos.almino@gmail.com

Financial source: none

Conflicts of interest: none

Received for publication: 30/10/2014

Accepted for publication: 06/01/2015

DESCRTORES - Cirurgia geral. laparoscópica. Bisturi ultrassônico.
RESUMO - Racional: A colecistectomia laparoscópica na técnica tradicional oclui o ducto cístico e a artéria cística por clipes cirúrgicos, que podem se deslocar ou desprender no pós-operatório, possibilitando a ocorrência de fístula biliar ou hemorragia. Objetivo: Relato prospectivo de série de casos de colecistectomias laparoscópicas sem uso de clipe cirúrgico, sendo que a ligadura e secção da artéria cística e do ducto cístico foram realizadas por meio de bisturi ultrassônico. Método: Foram incluídos 125 pacientes submetidos à colecistectomia laparoscópica sem utilização de clipe cirúrgico metálico, onde a ligadura da artéria e do ducto cístico e também a remoção da vesícula biliar de seu leito hepático foram realizadas por meio de tesoura ultrassônica. Realizouse teste de pressão reversa na vesícula biliar removida intacta do leito hepático para verificar a segurança da técnica. Resultados: A principal indicação cirúrgica foi a colelitíase. O tempo cirúrgico médio foi de $26 \mathrm{~min}$ e todas as vesículas biliares foram retiradas intactas do leito hepático. Não houve mortalidade e a taxa global de morbidade foi de $0,8 \%$, sem hemorragias ou fístulas. 0 teste de pressão reversa mostrou que o ducto cístico ocluído pelo bisturi harmônico suportou ao pelo menos $36 \mathrm{mmHg}$ de pressão sem que ocorresse nenhum vazamento. Conclusão: O bisturi harmônico é eficaz e seguro em colecistectomias laparoscópicas eletivas como um instrumento único para ocluir e seccionar tanto a artéria cística quanto o ducto cístico. Vantagens podem ser apontadas ao método com relação a sua segurança e diminuição do tempo cirúrgico.

\section{INTRODUCTION}

L aparoscopic cholecystectomy is accepted as the gold standard surgical methodology for the treatment of gallstones with advantages in comparison over open cholecystectomy especially by minimal invasiveness and faster convalescence ${ }^{19}$. In traditional laparoscopic cholecystectomy technique, the cystic duct and artery are commonly closed by metallic clips just before their division. Although the placement of these clips for occluding cystic artery and duct could be considered safe, biliary leaks and bleeding may occur especially by its dislodgement ${ }^{23}$.

Ultrasonic coagulating shears were developed to allow vessels surgical hemostasis and cutting of without bleeding during laparoscopic surgery, by its sealing effect, which is related to coagulation of protein through high frequency ultrasonic vibrations ${ }^{1}$. In cholecystectomy, the primary use of this device was as an energy form for cutting and coagulating during dissection and removal of the gallbladder from its liver bed ${ }^{2,16}$.

Several worldwide studies reported the clipless cholecystectomy by using 
the ultrasonically activated shears as the sole instrument to achieve complete hemo-biliary stasis (cystic duct and artery), most of them with case-series ${ }^{13,8,28,27,3,31,7,24,6,17,14,30}$. In these 1221 cases there was no hemorrhage reported and the overall incidence of postoperative bile leakage was in agreement with the literature showing that this technique seems to be as safe as the surgical clip.

Besides being equally safe, advantages to clipless cholecystectomy by means of harmonic shears versus conventional laparoscopic cholecystectomy is a shorter operative time, less incidence of gallbladder perforation, less postoperative pain and less rate of conversion to open cholecystectomy ${ }^{17}$.

According with these successful reports, herein is related the experience in using the harmonic shears for both gallbladder dissection and closure/division of the cystic duct and artery in laparoscopic cholecystectomy.

METHODS

\section{Patients}

Over a 15-month interval, all patients who underwent laparoscopic cholecystectomy, where the treatment of cystic duct and artery was achieved by means of harmonic/ ultrasonic energy (Ultracision $\AA$ - Ethicon Endosurgery) and operated by authors surgical team with same operative technique were studied and included in this case-series. The study analyzed the indication for surgery, operating time, conversion to open surgery, mean post-operative hospital stay, morbidity and mortality rate and performed a reverse pressure test for testing the safety of occluding cystic duct.

\section{Surgical technique}

The laparoscopic cholecystectomy was performed by 4-ports (three $5 \mathrm{~mm}$ and one $11 \mathrm{~mm}$ ) placed on the upper abdomen, with the patient lying in the supine position with legs apart and the surgeon stands between them. The following instruments were employed: a $10-\mathrm{mm} 30^{\circ}$ angle view scope, harmonic shears, grasping forceps and a 5-mm suction probe. The grasping forceps were inserted through the right flank $5-\mathrm{mm}$ cannula and the $5-\mathrm{mm}$ suction probe in the xiphoid position cannula. The forceps was used to grasp the infundibulum, making a rightward traction, and the probe used to make an upward traction of the liver, thus improving the exposure of Calot's triangle. At this point, all dissection maneuvers were carried out by bluntly harmonic shears. The cystic artery was isolated at first. Then the cystic duct was approached. After clear identification of both, the coagulation and division of cystic artery was carried out first with Ultracison ${ }^{\circledR}$ regulated in a power set " 3 " (median) and the ultrasonic shears were activated and keeping in place by approximately $5 \mathrm{~s}$ (time enough for coagulation and division). In sequence, the Ultracision ${ }^{\circledR}$ was downregulated to power level " 1 " (which translated into less cutting and more coagulation) and closure and division of cystic duct was reached by holding the jaws of the harmonic shears closed and activated until division of the duct is accomplished (median 15 seconds). In both case (artery and duct) were use the unique application of the ultrasonically activated shears. The blades were closed with kindness and the surgeon avoided excessive traction, allowing until the jaws of the shears were naturally detached from both, artery and duct cystic. Finally, gallbladder dissection and removal from the liver bed was carried out as usual with Ultracision ${ }^{\circledR}$ regulated in a power set " 5 " (maximum) and it was extracted involved in a plastic bag through the $11-\mathrm{mm}$ trocar.

\section{Reverse pressure test}

In the last 12 patients were carried out reverse pressure tests of the sealed cystic duct. Intact gallbladder was immersed into water recipient with a Veress needle punctured in the fundus. The laparoscopic insufflator was connected and gradually the gallbladder was filled by $\mathrm{CO}_{2}$. If any air-escape was observed (by bubbles-air), the pressure was recorded ("bursting pressure-like") (Figure 1).

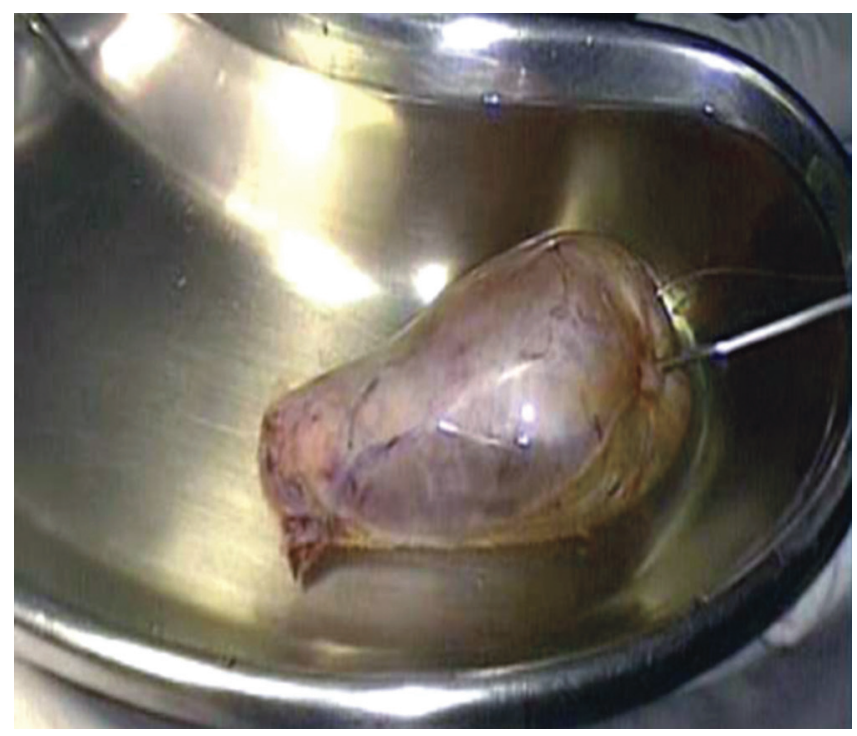

FIGURE 1 - Reverse pressure test: intact gallbladder air-filled by Veress needle punctured in the fundus and immersed into water recipient to observe any air-escape (bubbles-air)

\section{RESULTS}

In this sample, 125 patients (aged 22-68 years - median 45 -yo) were included ( 83 females and 42 males). There were no patients operated on an emergency basis. The indication for surgery was gallstones in 120 cases and there were five cases of gallbladder polyps. The mean operating time was 26 min (range 12 to 52) and no associated procedure was required. To be qualified for the technique the maximum diameter accepted for cystic artery and cystic duct was 5 $\mathrm{mm}$.

Conversion rate to open technique was zero and all gallbladders were dissected intact from liver bed. Intraoperative cholangiography was unnecessary in every case, according guided pre-operative clinical and laboratory examination (abdominal ultrasound, bilirubin and aminotransferases, alkaline phosphatase and gamaglutamiltransferase levels). Was not used any form of postoperative abdominal drainage.

Overall morbidity rate was $0.8 \%$ due to only a patient with abdominal pain in upper right, with spontaneous resolution up to $5^{\text {th }}$ postoperative day. Mean postoperative hospital stay was $12 \mathrm{~h}$. All patients demonstrated no clinical evidence of bile leakage or bleeding. The reverse pressure test showed that all specimens support at least $36-\mathrm{mmHg}$ $\mathrm{CO}_{2}$. At this level, no leak (bubbles-air) was observed through cystic duct sealed by harmonic shears. Mortality was nil.

\section{DISCUSSION}

Designed to be a safer and better alternative to electrocautery for the hemostatic dissection of tissues in general surgery, the ultrasonically activated shears carry out 
different functions gathered in one instrument (dissection, coagulation, cutting). By transforming the electric energy into ultrasound vibrations it may offer a lot of advantages for surgery technique, as closure and division of vessels up to $5 \mathrm{~mm}$ with safety.

Other great advantage of the harmonic scalpel or shears is the short area of thermal injury. The thermal damage in the rat abdominal wall is width less than 0.2 $\mathrm{mm}^{22}$ and in the liver bed from gallbladder dissection is lower than that of high-frequency electrosurgery ${ }^{10}$. This might allow the surgeon to use the harmonic dissector closely to anatomical structures like common bile duct with no fear of common bile duct thermal injury and posterior bile leakage.

Beyond being used as a dissector of the gallbladder from its liver bed, the harmonic shears as the sole instrument for hemobiliary stasis is controversial and still provoke some suspicion by surgeons. Technical details of the using this device in total clipless cholecystectomy was described in a book published and sponsored by European Surgical Institute ${ }^{15}$ with some European countries as Portugal, Spain an France using regularly this methodology.

As the coagulation function of harmonic shears is said by the manufacturer safe when applied to vessels of up to 5 $\mathrm{mm}$ and the cystic artery is usually not larger than that, the postoperative bleeding does not seem to be an expected complication.

Otherwise, sealing and division of the cystic duct with only harmonic shears is controversial and the fear that this is not enough to withstand the pressure and carry out a postoperative bile leak could be a limiting factor for its widespread use, especially in large cystic (greater than 5 $\mathrm{mm}$ ), which is a relative contraindication. In this study, there was no clinical bile leakage, which is according with others reports (Table 1 )

TABLE 1 - Incidence of bile leakage in harmonic shears experience in sealing and division of the cystic duct

\begin{tabular}{|c|c|c|c|}
\hline Author & year & N cases & bile leak \\
\hline Huscher et al. & 1999 & 50 & 1 \\
\hline Huscher et al. & 2003 & 331 & 7 \\
\hline Godina et al. & 2004 & 115 & 0 \\
\hline Westervelt et al. & 2004 & 98 & 0 \\
\hline Tebala et al. & 2006 & 100 & 0 \\
\hline Bessa et al. & 2008 & 60 & 0 \\
\hline Vu et al. & 2008 & 22 & 0 \\
\hline Gelmini et al. & 2010 & 78 & 0 \\
\hline Redwan et al. & 2010 & 80 & 0 \\
\hline Nakeeb et al. & 2010 & 60 & 1 \\
\hline Kandill et al. & 2010 & 70 & 0 \\
\hline Jain et al. & 2011 & 100 & 0 \\
\hline Wills et al. & 2013 & 57 & 1 \\
\hline Total & & 1221 & 10 \\
\hline
\end{tabular}

The report of highest rate of bile leaks occurred in a comparative study where one group was comprised by surgeon-in-training, precisely the group with the most of the leaks and technical aspects could then be involved in this occurrence outside normal patterns. Excluding this study from the sample analyzed, the rate of bile leaks drops to $0.33 \%$ (3/890), which is according to bile leaks from cystic duct occluding by clips ${ }^{29,11,20}$.

Although the reported bile leaks in clipless cholecystectomy occurred probably by temporary sealing of the cystic duct by harmonic shears, it is worth remind that post-cholecystectomy bile leaks most commonly occur due to injury of the common bile duct ${ }^{9}$ and could also come from a duct of Luschka ${ }^{25}$.

Comparative study with surgical clip sealing the cystic duct with harmonic shears had already proved its safety ${ }^{18}$. For setting out this, these authors also performed in 12 last cases the "reverse pressure test" and the gallbladder withstood the pressure by laparoscopic insufflator up to $36 \mathrm{mmHg} \mathrm{CO}{ }^{\prime}$ showing that the harmonic sealing is even safe, which was corroborated by the absence of clinical bile leakage. The airtight pressure of the sealed cystic duct had already been calculated as higher than normal intracystic pressure ${ }^{12}$. Although there is some controversy about the normal pressure of the common bile duct under normal conditions especially because it is not simple to determine it; the reverse test here done showed that the pressure supported seems to be higher than the intracystic normal pressure measured ${ }^{5,26}$. Suspicious of a high biliary pressure related to different conditions, as choledocolithiasis for instance, could be considered contraindication to cystic duct application of the ultrasonic shears.

As harmonic shears is a versatile multipurpose instrument, its use in laparoscopic cholecystectomy prevents the frequent extraction and reinsertion of different others instruments with no wasting time. Moreover, as the activation of the harmonic shears does not form a lot of smoking, only a slight mist, it is not necessary to evacuate the pneumoperitoneum to clean up the abdominal cavity so often, both contributing for shortening operative time, even using clips $^{4}$. These theorical advantages were also experienced in these 125 cases.

However unusual, interesting special advantage is the use of the harmonic energy in patients with heart pacemaker by avoiding electrical interference from conventional surgical diathermy ${ }^{21}$. Although the regular use of ultrasonic dissection represents a real advantage in comparison with regular electrocauterization, in the majority of the countries this will leads to some increase in the final cost of the procedure and this will represent difficulty, limiting the large acceptation of the method.

As the best of authors knowledge, this is the first Brazilian experience in total clipless cholecystectomy by means harmonic shears and the excellent results (fast operative time, quick hospital stay and especially no common bile duct injury or postoperative bile leak nor hemorrhage) enhanced to continue performing this technique in elective laparoscopic cholecystectomy whenever possible. However, it is believed that experimental studies in animal model and randomized clinical trials will offer valuable additional data for until now unanswered questions.

\section{CONCLUSION}

The ultrasonically activated shears is effective and safe in elective laparoscopic cholecystectomy as a sole instrument for sealing and division of the artery and duct cystic.

\section{REFERENCES}

1. Amaral JF. Ultrasonic dissection. Endosc Surg Allied Technol. 1994:2:181- 5.

2. Amaral JF. Laparoscopic cholecystectomy in 200 consecutive patients using an ultrasonically activated scalpel. Surg Laparosc Endosc. 1995;5:255-62.

3. Bessa SS, Al-Fayoumi TA, Katri KM, Awad AT. Clipless Laparoscopic Cholecystectomy by Ultrassonic Dissection. J Laparosc Adv Surg Tech. 2008;18:593-8.

4. Cengiz $Y$, Janes $A$, Grehn $A$, Israelsson LA. Randomized clinical trial of traditional dissection with electrocautery versus ultrasonic fundus-first dissection in laparoscopic cholecystectomy. Br J Surg. 2005;92:810-3 
5. Davenport M, Basu R. Under pressure: choledochal malformation manometry. J Pediatr Surg. 2005;40:331-5.

6. El Nakeeb A, Askar W, El Lithy R, Farid M. Clipless laparoscopic cholecystectomy using the Harmonic scalpel for cirrhotic patients: a prospective randomized study. Surg Endosc. 2010;24:2536-41.

7. Gelmini R, Franzoni C, Zona S, Andreotti A, Saviano M. Laparoscopic cholecystectomy with Harmonic scalpel. JSLS 2010;14:14-9.

8. Gòdina M, Tasinato R, Bragato N, Bettineschi F, Menegon P, Griggio $\mathrm{L}$ (2004) Laparoscopic cholecystectomy utilizing a harmonic scalpel.

9. Heng-Hui Lien, Ching-Shui Huang, Min-Yen Shi, Der-Fang Chen, Nai-Yuan Wang, Feng-Chuan Tai et al. Management of Bile Leakage After Laparoscopic Cholecystectomy Based on Etiological Classification. Surg Today. 2004;34:326-30.

10. Hochstadetr H, Bekavac-Beslin M, Doko M, Kopljar M, Cupic H, Glavan E et al. Functional Liver Damage during Laparoscopic Cholecystectomy as the Sign of the Late Common Bile Duct Stricture Development. Hepatogastroenterology 2003;50:676-9.

11. Huang X, Feng Y, Huang Z. Complications of laparoscopic cholecystectomy in China: an analysis of 39,238 cases. Chinese Med J. 1997;110:704-6.

12. Huscher CGS, Lirici MM, Anastasi A, Sansonetti A, Amini M. Laparoscopic cholecystectomy by harmonic dissection. Surg Endosc. 1999;13:1256-7.

13. Huscher CGS, Lirici MM, Di Paola M, Crafa F, Napolitano C, Mereu A et al. Laparoscopic cholecystectomy by ultrasonic dissection without cystic duct and artery ligature. Surg Endosc. 2003;17:442-51.

14. Jain SK, Tanwar R, Kaza RC, Agarwal PN. A prospective, randomized study of comparison of clipless cholecystectomy with conventional laparoscopic cholecystectomy. J Laparoendosc Adv Surg Tech. 2011;21:203-8.

15. Janes A. Clipless laparoscopic cholecystectomy with Harmonic. Euromed Communications, European Surgical Institute, United Kingdom, 2006.

16. Janssen IMC, Swank DJ, Boonstra O, Knipscheer BC, Klinkenbijl JHG, van Goor H. Randomized clinical trial of ultrasonic versus electrocautery dissection of the gallbladder in laparoscopic cholecystectomy. Br J Surg. 2003;90:799-803.

17. Kandil T, El Nakeeb A, El Hefnawy E. Comparative study between clipless laparoscopic cholecystectomy by harmonic scalpel versus conventional method: a prospective randomized study. J Gastrointest Surg. 2010;14:323-8.
18. Kavlakoglu B, Pekcici R, Oral S. Verification of clipless closure of cystic duct by harmonic scalpel. J Laparoendosc Adv Surg Tech. 2010;20(7):591-5.

19. Keus F, Gooszen HG, Van Laarhoven CJHM. Systematic review: open, small-incision or laparoscopic cholecystectomy for symptomatic cholecystolithiasis. Aliment Pharmacol Ther. 2008;29:359-378.

20. Miroshnik M, Saafan A, Koh S, Farlow J, Neophyton J, Lizzio J et al. Biliary tract injury in laparoscopic cholecystectomy: results of a single unit. ANZ J Surg. 2002;72:867-70.

21. Nandalan SP, Vanner RG. Use of the harmonic scalpel in a patient with a permanent pacemaker. Anaesthesia 2004;59:621.

22. Perko Z, Pogorelic Z, Bilan K, Tomic S, Vilovic K, Krnic D et al. Lateral thermal damage to rat abdominal wall after harmonic scalpel application. Surg Endosc. 2006;20:322-4.

23. Power C, Maguire D, McAnena OJ, Calleary J. Use of the ultrasonic dissecting scalpel in laparoscopic cholecystectomy. Surg Endosc. 2000;14:1070- 3 .

24. Redwan AA. Single-working-instrument, double-trocar, clipless cholecystectomy using harmonic scalpel: a feasible, safe, and less invasive technique. J Laparoendosc Adv Surg Tech. 2010;20:597-603.

25. Rulli F, Grasso F. Biliary peritonitis for duct of Luschka bile leak after laparoscopic cholecystectomy performed with a $10-\mathrm{mm}$ harmonic scalpel. Langenbecks Arch Surg. 2007;392:111-2.

26. Sharma N, Bhatnagar V, Srinivas M, Agarwala S, Singh MK, Sharma R. Correlation of intracystic pressure with cyst volume, length of commonchannel, biochemical changesin bileand histopathological changes in liver in choledochal cyst. J Indian Assoc Pediatr Surg. 2014;19:10-6.

27. Tebala GD. Three-port laparoscopic cholecystectomy by harmonic dissection without cystic duct and artery clipping. Am J Surg 2006;191:718-20

28. Westervelt J. Clipless Cholecystectomy: Broadening the Role of the Harmonic Scalpel. JSLS 2004;8:283-5.

29. Wise US, Glick GL, Landeros M. Cystic duct leak after laparoscopic cholecystectomy: a multiinstitutional study. Surg Endosc. 1996;10:1189-93.

30. Wills E, Crawford G. Clipless versus conventional laparoscopic cholecystectomy. J Laparoendosc Adv Surg Tech. 2013;23:237-9.

31. Vu T, Aguilo R, Marshall NC. Clipless technique of laparoscopic cholecystectomy using the harmonic scalpel. Ann R Coll Surg Engl. 2008;8:612-618. 